技術報告

\title{
簡易な農業技術体系Web データベースの試作
}

\author{
南石晃明 ${ }^{1)}$ ・本田茂広 ${ }^{2)}$
}

1) 中央農業総合研究センター † 305-8666 茨城県つくば市観音台 3-1-1

2) 三菱スペース・ソフトウエア株式会社 テ 305-0047 茨城県つくば市千現 1-17-15

\section{はじめに}

営農計画の作成や農業技術の評価には，既存の 農業技術体系に関する情報が不可欠である。この ため各都道府県では, 「○○県主要作物の技術・ 経営指標」や「○○県農業経営指標事例集」等之 言った名称でいわゆる「標準技術体系」に関寸る データを主に印刷物の形態として取りまとめてい る.こうしたデータは従来, 各都道府県における 内部利用が前提とされており，全国べースの「標 準技術体系」の利用は困難であった。

そこで，土田ら（2000）は，各都道府県作成の 「標準技術体系」を収集し，データ利用の許可が 得られた 31 都府県のデータについて編集作業を 行い, 可能な限り統一した形式によって要約的な データを整理すると共に，表計算ソフト（MSExce1）形式で作成した各都道府県データファイ ルを格納した CD を作成した。しかし，各都府県 データの形式や記載方法が多様であったためデー タベース化がなされておらず，データベース構築 が課題となっていた。 今回, 都府県データの横断 的な検索を可能にする簡易な Web データベースの 試作を行ったので, 本報告では, その概要を紹介 すると共にデータベース構筑上の課題についても 述べる。

\section{システムの構成}

土田ら（2000）に添付されているCD「県別・作 目別の収支データ・利益係数・技術係数データ ファイル」（以下，本データファイル）のデータ を，リレーショナルデータベース化し，データ ベースに対する検索用WWWインタフェースを構築
した．図1 はデータファイルの例である。この データファイルでは, 概水以下の項目に沿って データが整理されている。
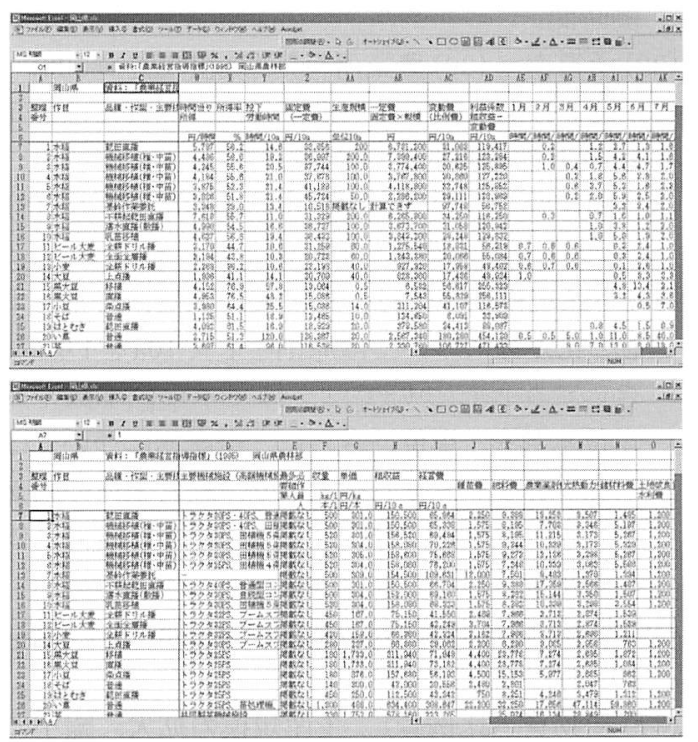

図1 データファイル例

（1）作目：各県の標準技術体系に記載されたもの をそのまま記載.

(2) 品種・作型・主要技術等 : 関連情報の記述が ある場合は記載.

(3) 主要機械施設 (高額機械施設) : 利用機械施設 について記述がある場合は主要な高額機械施 設名, 性能, 台数等を記載.

(4) 最多必要組作業人員 : 各作目の各作業毎に必 要とする組作業人員を記載.

（5）収量：作物によって単位が異なる. 10a 当た り $\mathrm{kg}$, 販売本数や鉢数など. 
（6）単価 : 多くの場合，各県の標準技術体系に掲 載された販売単価を記載.

(7) 粗収益 : 多くの場合，各県の標準技術体系に 記載された粗収益を記載.

(8) 経営費 : 以下の費目から構成されている. (9) 種苗費, (10) 肥料費, (11) 農業薬剤費, (12) 光 熱動力費, (13) 諸材料費, (14) 土地改良水利 費, (15) 賃借料料金, (16) 出荷経費，（17）その 他変動費, (18) 小農具費, (19) 農機具費, (20) 建物施設費, (21) 成園費, (22) 減価償却費, （23）修繥費，（24）雇用労働費，(25）共済 - 保険 料, (26) 支払利子, (27) 支払地代, (28) 租税公 課, (29) その他.

(30) 農業所得 $=(7)$ 粗収益 $-(8)$ 経営費.

(31) 時間当たり所得＝(30) 農業所得 $/(33)$ 投下労 働時間.

(32) 所得率 $=(30)$ 農業所得 $/(7)$ 粗収益 $\times 100$.

(33) 投下労働時間 : 月別投下労働時間または月旬 別投下労働時間の合計值.

（34）固定費（一定費）：費用が固定的である (18) 〜 (23)までの費目（10aあたり）を計上.

(35) 生産規模 : 単位は, 稲, 麦, 大豆, 野菜, 果 樹, 花卉等については原則として $10 \mathrm{a}$ を 1 単位. きのこ生産については，ほだ木単位本数や瓶 単位本数を 1 単位.さらに, 畜産物については 1 頭, 鷄は千〜万羽を 1 単位. 経営全体の収支 データや労働時間を示したものは, 経営全体 を 1 単位.

（36）年減価償却費 $=(34)$ 固定費 $\times$ (35) 生産規模. 10aあたり。

（37）変動費（比例費）: 生産規模の拡大, 縮小に 比例して増減する（9）～(17) までの費目.

(38) 利益係数 $=(7)$ 粗収益 $-(37)$ 変動費

（39）月別投下労働時間 : 各県の標準技術体系に掲 載されたデータをそのまま記載.

(40) 月旬別投下労働時間 : 各県の標準技術体系に 掲載されたデータをそのまま記載.

リレーショナルデータベースおよびWWW イン タフェースは, OS としてLinuxを使用した PC/ AT 互換機で動作する. 表 1 に H/W および $\mathrm{S} / \mathrm{W}$ 環 境を示す. D B M S にはフリーソフトである， PostgreSQL7. 1. 1 を使用した. RDB サーバは将来
変更されることを考え, 極力標準的な SQL を使 用するようにしたが，コード（キー）に自動連 番を割り振るために serial 型, 前提条件を格納 するための TEXT 型など, PostgreSQL 独自の機 能を使用している. また, 高速検索のためイン デックスを作成しているが，この作成方法も使 用するデータベースに依存することにも注意が 必要である。

\section{表1 システム開発環境}

1）ハードウェア環境

\begin{tabular}{|l|l|}
\hline CPU & Intel Celeron $333 \mathrm{MHz}$ \\
\hline Memory & $256 \mathrm{MB}$ \\
\hline Disk & $8 \mathrm{~GB}$ \\
\hline
\end{tabular}

2) ソフトウェア環境

\begin{tabular}{|l|l|}
\hline 開発言語 & Perl5 \\
\hline DBアクセスモジュール & Pg \\
\hline リレーショナルデータベース & PostgreSQL7 \\
システム & \\
\hline WWWサーバ & Apache1 \\
\hline
\end{tabular}

本データファイルは, Microsoft Excelにより 作成されたファイルとして県別に分割された形 式で提供されている. これらをリレーショナル データベースに格納するために以下の作業を 行った.

\section{テーブル構造の設計}

データベースは 15 のテーブルから構成されて おり, リレーション図を図 2 に示す. 種苗費など の細目は各県によって, 項目名, 項目数ともに異 なっていた. このデータベースでは, 全ての項目 名をカバーする経営費テーブルと作物毎にデー タの存在有無を示す経営費フラグテーブルを持 たせた.また，これらの項目から算出できる，固 定費, 変動費などもばらつきにより単純に計算 させることができなかったため，正規化せずに 值そのものをデータベースに持たせた. 現在, データベースには 2924 件の技術体系（作目）が 登録されており,このうち品種・作型・主要技術 の記載があるのは 1051 件, 主要機械施設の記載 があるのは 415 件である. 


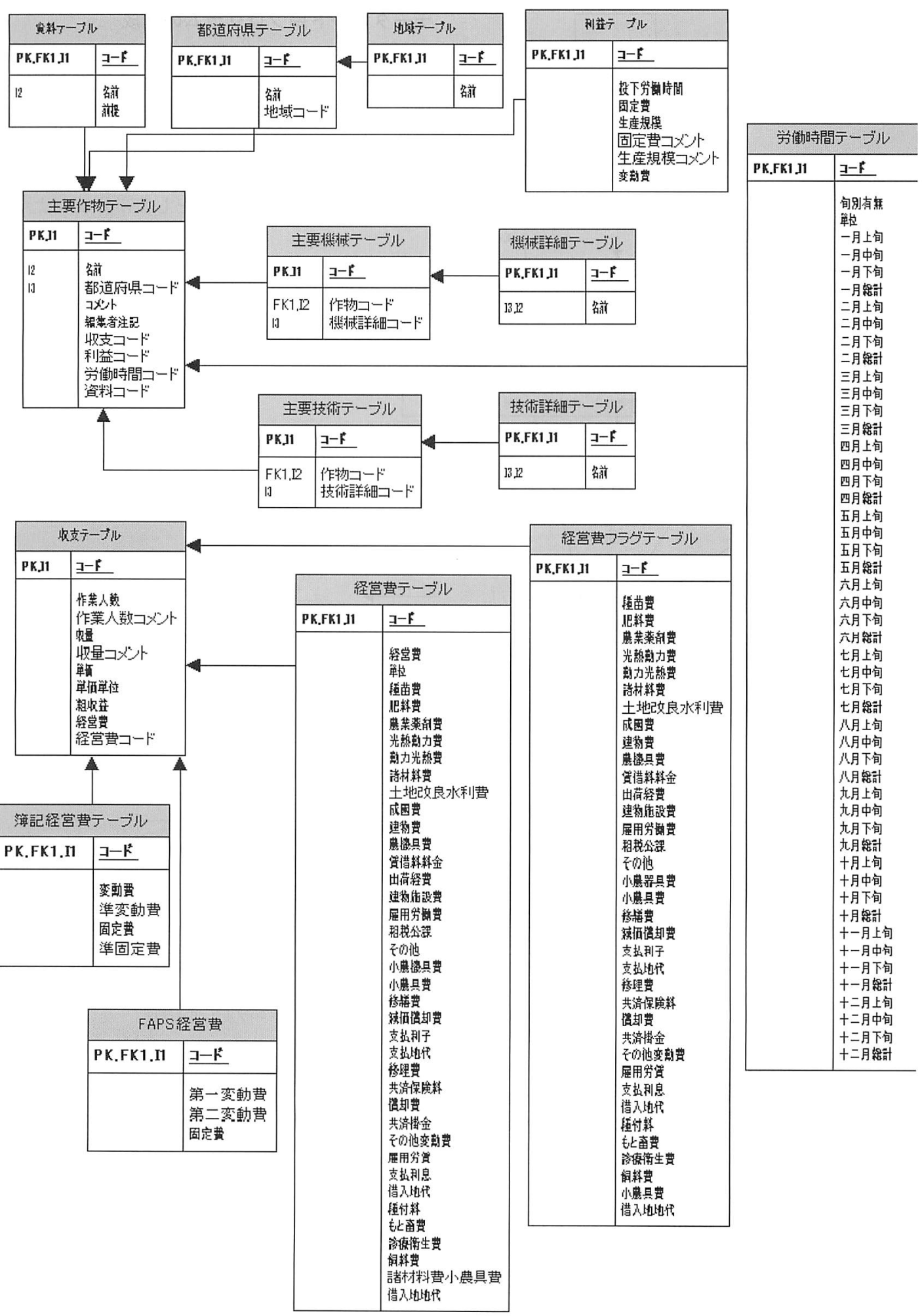

図2リレーション図 


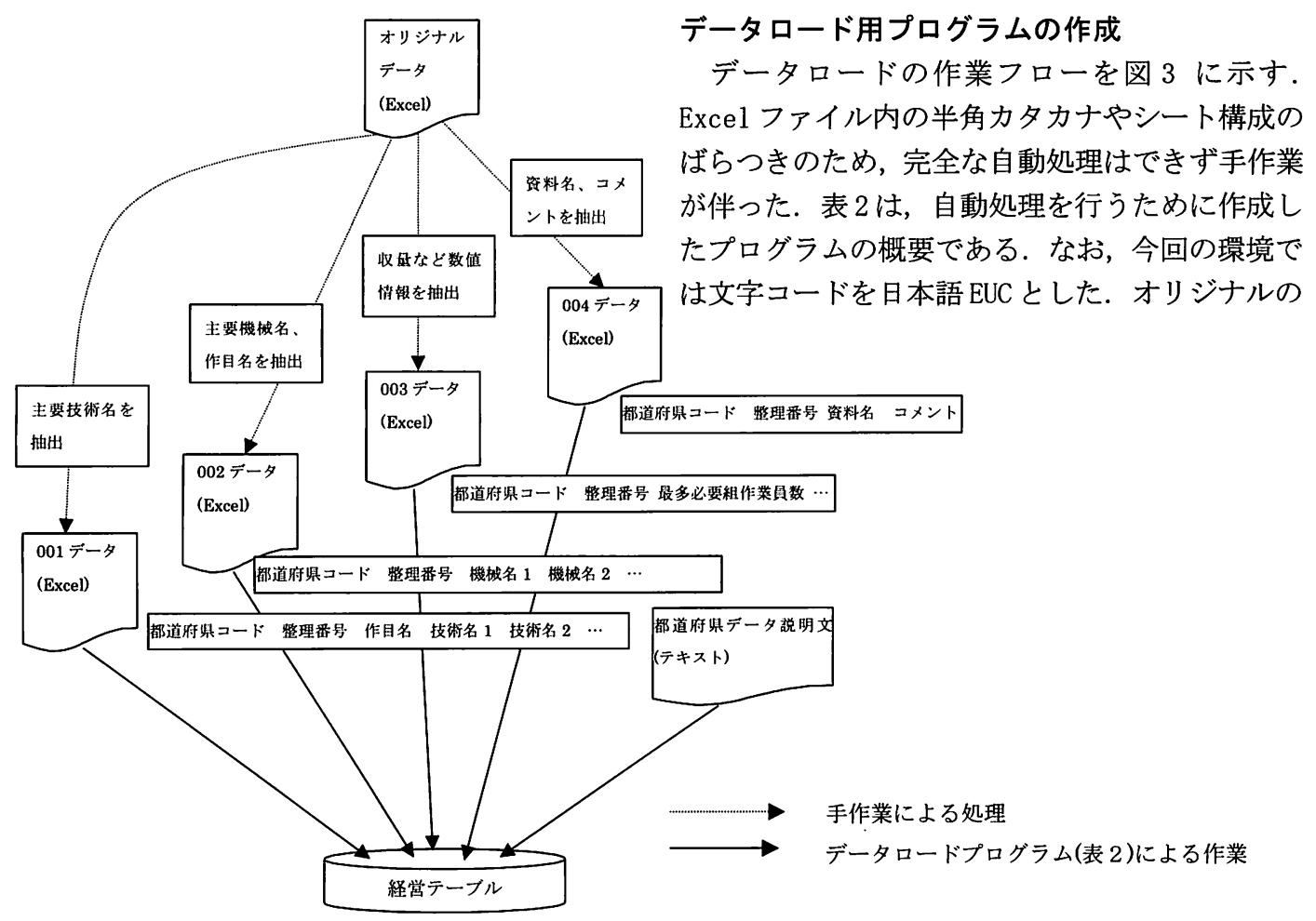

図3 データベース構築フロー

表2 データロードプログラム一覧

\begin{tabular}{|c|c|c|c|}
\hline $\begin{array}{l}\text { 番 } \\
\text { 号 }\end{array}$ & プログラム名称 & 言語 & 内容 \\
\hline 1 & createtable.sql & SQL & テーブル定義, インデックスの作成を行う. \\
\hline 2 & $\begin{array}{l}\text { loadTiikiAndTodouhuk } \\
\text { en.pl }\end{array}$ & Perl & $\begin{array}{l}\text { 都道府県データから都道府県テーブル, 地域テー } \\
\text { ブルを作成する }\end{array}$ \\
\hline 3 & loadGijutu_detail.pl & Perl & 001 データから技術詳細テーブルを作成する. \\
\hline 4 & loadKikaiDetail.pl & Perl & 002 データから機械詳紐テーブルを作成する. \\
\hline 5 & loadSakumotu001.pl & Perl & 001 データから主要作物テーブルを作成する. \\
\hline 6 & loadGijutu.pl & Perl & $\begin{array}{l}\text { 主要作物テーブルと技術詳細テーブルの関連付け } \\
\text { を行い，技術テーブルを作成する. }\end{array}$ \\
\hline 7 & loadKikai.pl & Perl & $\begin{array}{l}\text { 主要作物テーブルと機械詳細テーブルの関連付け } \\
\text { を行い, 機械テーブルを作成する. }\end{array}$ \\
\hline 8 & loadSyuusi.pl & Perl & 003 データから収支テーブルを作成する. \\
\hline 9 & loadSiryou.pl & Perl & 004 データから資料テーブルを作成する. \\
\hline 10 & loadRiekiXXXX.pl & Perl & $\begin{array}{l}003 \text { データから利益テーブルを作成する．XXXX } \\
\text { は県名を示す. }\end{array}$ \\
\hline 11 & loadKeieihiXXXX.pl & Perl & $\begin{array}{l}003 \text { データから経営費テーブルを作成する. XXXX } \\
\text { は県名を示す. }\end{array}$ \\
\hline 12 & loadRoudoujikan.pl & Perl & 003 データから労働時間テーブルを作成する. \\
\hline 13 & load.sh & $\begin{array}{l}\mathrm{B} \text { シ } \\
\text { エル }\end{array}$ & 1 から 9 までのプログラムを実行する. \\
\hline 14 & loadKenbetu.sh & $\begin{array}{l}\mathrm{B} \text { シ } \\
\text { エル }\end{array}$ & 10 から 12 までのプログラムを実行する. \\
\hline
\end{tabular}


1 バイト仮名文字や外字の変換は全て手作業で 行った.

都道府県コードはJIS X 0401：1973を使用した。 ただし，若名県に刘応するため未使用の 48 以降 老使用している。今回は県名が匿名のA 県につい ては 99 を使用した。また，地区による検索が可 能になるよう，各県の属する地区についてもデー タベース化した。 また，品種・作型・主要技術及 び主要機械施設を個別に検索できるように，オリ ジナルから分割した。この際，例えば「キャンベ ル・アーリー・露地」のように単純に「・」で区 切ることができないものや，「トンネル栽培」, 「トンネル」のように表現にぶれが存在した。現 在のデータベースではそのまま入力している。ま た，「夏まき八ウス栽培」を「夏まき」,「八ウス 栽培」と分割したため,「夏まき」と「夏まき栽 培」というぶれを生成している。

なお，富山県のデータの一部に複合経営の情報 がないため，営農で使用する機械の情報に不具合 があった，例えば，「りんご」に対し「田植機」が 記載されていた。今回はオリジナルのまま使用し ている. 山梨県, 整理番号 24 の作目名に間違い があった。これを「ソルダム」と修正した。山梨 県, 整理番号 76 が 3 個存在した。今回は 3 番目の データを使用した。

\section{システムの機能と課題}

農業技術体系WebDB (http://ainfo, mi. mss.co.jp/cgi-bin/selectRegion.cgi）は, 都 道府県名, 作目名, 主要機械名, 主要技術名を キーワードとして，Web から検索できる。技術 体系データは各都道府県が独自に作成してお り, 品種, 作型, 主要技術, 主要機械・施設名, 経営費細目などの記載内容が統一されていな い.このため，キーワードを自由に入力しても 意図した検索結果ができないため, DB に登録済 みの単語から選択することもできる仕様とし た。また，作目名，主要機械名，主要技術名に キーワードを含む全ての技術体系を検索するこ とも可能にした。例えば，作物名＝水稲，主要 技術体系名＝直播の条件でディフォルト検索す ると，富山県の技術体系 5 件が検索されるが， 「キーワードを含む全ての技術体系を検索する」 場合には，これに加えて岡山，鳥取，京都の技 術体系を含めた 10 件が検索される。検索結果で は，営農技術体系評価・計画システムFAPS の費 用項目（第 1 変動費，第 2 変動費，固定費）別 の集計值なども算出される.

検索結果表示画面の最後では, (1) 検索システ

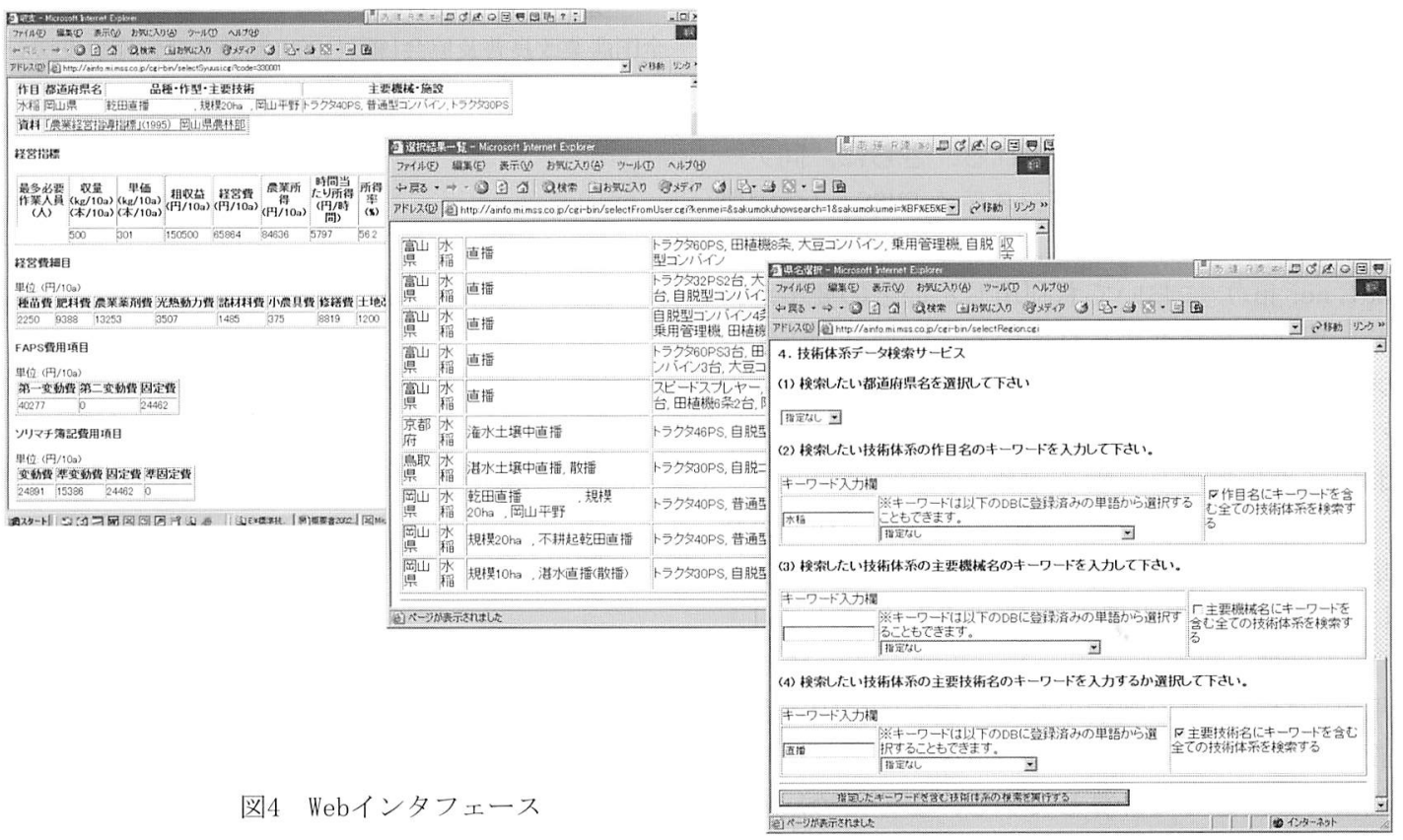


ムの説明，(2) キーワードの設定，(3) 検索速度，(4) 検索結果の表示の仕方, (5) 検索結果のデータの有 効性，の 5 項目について，5段階の評価を行うア ンケートを実施した。1 1 月間の総ヒット数は 269 であり, 作物検索, 都道府県作物検索が過半 数を占めた. アンケート回答数は 10 件であり， キーワードの設定では「普通」や「やや使いにく い」との回答が多く，検索結果の表示の仕方で は,「普通」が多かった.これ以外の項目では,「普 通」と「分かりすい」，「速い」，「役立つ」といっ たポジティブな回答に概ね二分された.

表3 システム利用者の評価

\begin{tabular}{|c|c|c|c|c|c|}
\hline 项目 & 分択肢 1 & $\begin{array}{l}\text { 遢択 } \\
\text { 肢 } 2 \\
\end{array}$ & 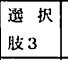 & $\begin{array}{l}\text { 拈 択 } \\
\text { 肢 } 4\end{array}$ & 䢤抧肢 5 \\
\hline 本檢枽システムの説明 & $\begin{array}{l}\text { 分かりやナい } \\
4\end{array}$ & 1 & \begin{tabular}{|l|l|} 
蕾通 \\
4 \\
\end{tabular} & 1 & $\begin{array}{l}\text { 分かりにくい } \\
0\end{array}$ \\
\hline $\begin{array}{l}\text { キーワードの設定なと本検索 } \\
\text { システム }\end{array}$ & $\begin{array}{l}\text { 使いやすい } \\
1\end{array}$ & 1 & \begin{tabular}{|l} 
事通 \\
5 \\
\end{tabular} & 3 & $\begin{array}{l}\text { 使いにくい } \\
0\end{array}$ \\
\hline 検索速度 & $\begin{array}{l}\text { 速い } \\
5\end{array}$ & 2 & \begin{tabular}{|l} 
亚迎 \\
3 \\
\end{tabular} & 0 & $\begin{array}{l}\text { 展い } \\
0 \\
\end{array}$ \\
\hline 検索結果の装示の仕方 & $\begin{array}{l}\text { 有効だ } \\
0 \\
\end{array}$ & 2 & $\begin{array}{l}\text { 事通 } \\
8 \\
\end{array}$ & 0 & $\begin{array}{l}\text { 有効でない } \\
0\end{array}$ \\
\hline 换索結果のデータ & $\begin{array}{l}\text { 役立つ } \\
4\end{array}$ & 1 & 4 & 1 & $\begin{array}{l}\text { 役立たない } \\
0\end{array}$ \\
\hline
\end{tabular}

注)回答者数は 10 人。

本稿で対象とした農業技術体系データは，現在 「新規就農シミュレーション・システム」（全国農 業会議所・全国新規就農相談センター, http:// www. nca. or. jp/Be-farmer/) で利用されており， 利用者や関係機関の関心も高い。これはデータ ベース内蔵により利用者の負担が軽減されている ことが要因の一つと考えられる.さらに，同デー 夕は「新・経営指導支援システムFMSS」(全国農 業改良普及協会, 1999 , ht tp: / / www.einet.ne. jp/) においても利用したいとの要望があ り，現在作業が進められている．営農計画支援シ ステムの実用化には体系的な農業技術体系データ ベースの整備が不可欠であることは既存の研究に おいても指摘されている（南石，2002）。

ところで，経営費は一般に設定された作物の栽 培面積に比例して費用が増加する変動費と, 面積 に比例しない固定費から構成される。しかし， 「新規就農シミュレーション・システム」では利 用可能なデータの制約のため, 便宜的に固定費= 設定された作物の栽培面積 $\times 10$ アールあたり減 価償却費，として計算している。このため, 経営
指標データで想定している栽培面積と設定した 栽培面積が異なる場合には; 固定費の額が実際 と大きく異なる場合もあることが問題となる。 また，予め集計された費用項目がデータとして 格納されており，資材の投入量や投入する資材 を変更した場合の費用が得られないといった問 題点もある.

今後は，機械・施設データベースや資材データ ベースを整備し, 営農計画や農業技術評価を行 う際に実態に即した機械・施設費や資材費が利 用できるようにする必要がある. また, 畜産や花 去等では生産単位が「10a あたり」や「kg」では ないため, 多様な単位が混在したデータを取り 扱えるデータベース構造が求められている. 操 作面では, シソーラスデータベースの整備など により，多様な表現・用語で記載された技術体系 データを統一的に検索できるような工夫も必要 となる.

\section{引用文献}

南石晃明(2002)営農技術体系評価・計画システムFAPSの 開発, 農業情報研究, 第11(2): 141-160.

土田志郎・南石晃明・門間敏幸 (2000) 県別 ・ 作物別の収 支データ・利益係数・技術係数データファイル (CD 付き). 経営管理プロジェクト成果集No. 2, 農業研 究センター, $371 \mathrm{pp}$.

全国農業改良普及協会[編] (1999) 新農業経営指導支援シ ステム新FMSS活用マニュアル, 153pp. 